\title{
Traditional and Artisanal Beverages in Nigeria: Microbial Diversity and Safety Issues
}

\author{
Ogueri Nwaiwu ${ }^{1, *(\mathbb{D}, \text { Chiugo Claret Aduba }}{ }^{2}$, Victor Chukwunenye Igbokwe ${ }^{3}$, \\ Chizoba Evelyn Sam ${ }^{3}$ and Michael Ukwuru Ukwuru ${ }^{4}(\mathbb{D}$ \\ 1 Food, Nutrition and Dietetics Division, University of Nottingham, Sutton Bonington Campus, \\ Nottingham NG7 2RD, UK \\ 2 Department of Science Laboratory Technology, University of Nigeria, Nsukka 41001, Nigeria; \\ chiugo.aduba@unn.edu.ng \\ 3 Department of Microbiology, University of Nigeria, Nsukka 41001, Nigeria; vickozby@gmail.com (V.C.I.); \\ evelyn.sam@unn.edu.ng (C.E.S.) \\ 4 Department of Food Science and Technology, Federal Polytechnic, Idah 271101, Nigeria; \\ mikeukwuru@gmail.com \\ * Correspondence: ogueri.nwaiwu@alpha-altis.co.uk
}

Received: 10 June 2020; Accepted: 18 August 2020; Published: 20 August 2020

\begin{abstract}
A review of up to 90 articles on the microorganisms associated with important artisanal or traditional beverages in Nigeria was carried out. This resulted in an overview of the prevalent microorganisms associated with soymilk, nono (fermented cow milk), tiger nut milk, yoghurt, kunu, zobo, palm wine and the local beers pito and brukutu. The bacteria genera, namely Bacillus, Escherichia, Lactobacillus, Staphylococcus, and Streptococcus, were detected in all nine beverages. On the contrary, this survey resulted in finding that the genera Saccharomyces, Aspergillus, Candida, and Penicillium were the eukaryotic microorganisms isolated in all beverages. The occurrence of fungal isolates, which can be responsible for producing mycotoxins, is a concern and shows the need for post-production tests. Overall, there is a low prevalence of bacteria associated with hygiene, especially the Escherichia genus in alcoholic beverages such as palm wine, pito and burukutu, which may be due both to a low acidity and high ethanol content. However, the prevalence of hygiene indicator genera was higher in nonalcoholic drinks, probably because of incorrect practices during processing. The magnitude of the production and sales of unregulated local beverages in Nigeria has reached the stage where significant regulation and food safety standards are required to safeguard public health. An opportunity exists to monitor and characterize the microbial flora of the artisanal beverages using molecular methods at all stages of production and storage.
\end{abstract}

Keywords: food safety; artisanal; bacteria; yeasts; fungi; traditional beverages; hygiene indicator organisms

\section{Introduction}

Unregulated beverages are commonly referred to as artisanal, unrecorded, illicit, or illegal drinks in a community. A common attribute of these kinds of products is that they are produced outside government regulation without any rules or regard to standard food safety guidelines. They could be home-made, surrogate, and counterfeit alcoholic beverages that predispose people to hazardous substances [1]. An unrecorded beverage can also be nonalcoholic and a country such as Nigeria has its fair share among other products found in different parts of the world. These kinds of products are generally untaxed by the government and anybody can become a manufacturer. A feature of unregulated beverages is that they are prone to food fraud and sometimes producers often claim that 
their products with substituted components give more nutrients than regulated beverages. It has been pointed out that beverages such as fruit juices, coffee, tea and alcoholic beverages are likely to be targets of food fraud by adulteration through practices, which may involve mixing or substituting the original components [2]. The packaging could also be compromised because, in Nigeria, many producers sell their products in used plastics that may not be sanitary.

Some illegal local energy drinks are high in caffeine and caffeine intoxication may result in tachycardia, vomiting, cardiac arrhythmias, seizures, or death [3]. The abuse of alcohol using local drinks may lead to unfavourable health conditions because a high consumption is linked with stroke, coronary heart disease and risk of death from aortic aneurysm [4]. Apart from obesity and diabetes, sugar-sweetened beverages are associated with hyperuricaemia and gout [5] and an increased mortality [6]. The lack of extensive regulations for most local products in developing countries such as Nigeria can affect public health because these products often contain compounds that are fermented by microorganisms, which may lead to food infection, intoxication, renal failure and other chronic illnesses. Sometimes a product may be regulated at the production stage but not during sales where the products can be displayed and sold under direct sunlight or inappropriate temperatures.

Tamang et al. [7] have emphasised that culturable and nonculturable microorganisms naturally ferment the majority of global fermented food and beverages and that traditional food fermentation represents an extremely valuable cultural heritage in most regions, and harbours a huge genetic potential of hitherto undiscovered strains. They recommended that holistic approaches for the identification and complete profiling of microorganisms in global fermented foods are beneficial. In other reports [8] it was pointed out that spontaneous food fermentations pose potential risks to human health and that the spontaneous fermentation by autochthonous microorganisms in artisanal beverages requires a careful understanding and controlled processes to avoid food poisoning $[9,10]$. Hence, the need for a transdisciplinary assessment to determine the actual trends and risk avoidance has been suggested [11].

In Nigeria, there are several local unregulated drinks produced by microbial fermentation that are important and tied to the socio-economic lives of many people. A good number of families rely on home-made beverages and sell them in the streets to provide an additional source of income. Some drinks, such as fermented palm wine [12], pito [13] and burukutu [14], are alcoholic whereas others, such as nono [15], are milk-based. Local yoghurts may be from animal or plant-based milk [16]. Other plant-based milk products include tiger nut milk [17] and soymilk [18]. The beverages kunu [19] and zobo [20] maybe sugar-sweetened during production with table sugar and there are many variants of these drinks. Epidemic disease outbreaks from the consumption of contaminated products in Nigeria are not well monitored due in part to the reluctance by public health authorities to rapidly confirm and respond to outbreaks [21].

The World Health Organization has reported that the prevalence of heavy episodic drinking (HED), which is defined as consumption of 60 or more grams of pure alcohol, remains as high as $60 \%$ in some sub-Saharan African countries [22]. The HED prevalence could be much higher if all unregulated spirits, which sometimes lead to fatalities, are taken into consideration. Fatalities from the consumption of unregulated beverages, especially distilled gin from palm wine in Nigeria, have been reported. The case of methanol poisoning [23], which killed 89 persons and caused a ban on the local distillation of gin from palm wine, was highlighted.

A concern which may lead to the microbial contamination of unregulated artisanal local drinks in Nigeria is poor hygiene. Poor hygiene organisms can occur at any point during the production or storage of finished products and public sales. Around the world, it is known that poor hygiene in developing countries contributes to the proliferation of food pathogens in several local beverages. The origin of bacterial or fungal contaminations during the processing of many local food and beverages in Nigeria is unclear and the prevalence of microorganisms needs further characterization. Besides, microbial fermentation products of local drinks in Nigeria are poorly studied while it has been shown that the microorganisms responsible for the fermentation of traditional drinks may produce other 
compounds or derivatives, which are harmful to health [24]. Therefore, this work aims to review different microbial genera already associated with some unregulated beverages in Nigeria and the impact it may have on public health. Future microbiological needs and regulatory requirements are highlighted.

To generate queries for the search activities, the name of the local drink and Nigeria were used for a search on the databases Web of Science, Pubmed, Google Scholar and Scopus such as so, "Pito and Nigeria" and so on. The drinks searched were yoghurt, nono, soymilk, tiger nut milk, zobo, kunu, pito, burukutu, and palm wine due to their popularity. Duplicate reports were removed and no less than 10 studies carried out in Nigeria for each drink that detected organisms were selected and analyzed to get an overview of the microorganisms present. The microbes were recorded to the genus level and the most prevalent genera that appeared in the studies were highlighted.

\section{Milk and Milk-Like Products}

The milk beverages (cow and plant-based) that could be sold unregulated are shown in Figure 1. Apart from nono (Figure 1B) which is mainly sold in bowls, the other milk products-soymilk (Figure 1A), tiger nut milk (Figure 1C), and yoghurt (Figure 1D)_are usually marketed with plastic bottles in cities. Sometimes the yoghurts marketed may just be fermented nono that are packaged and sold [25] without regulation.

A

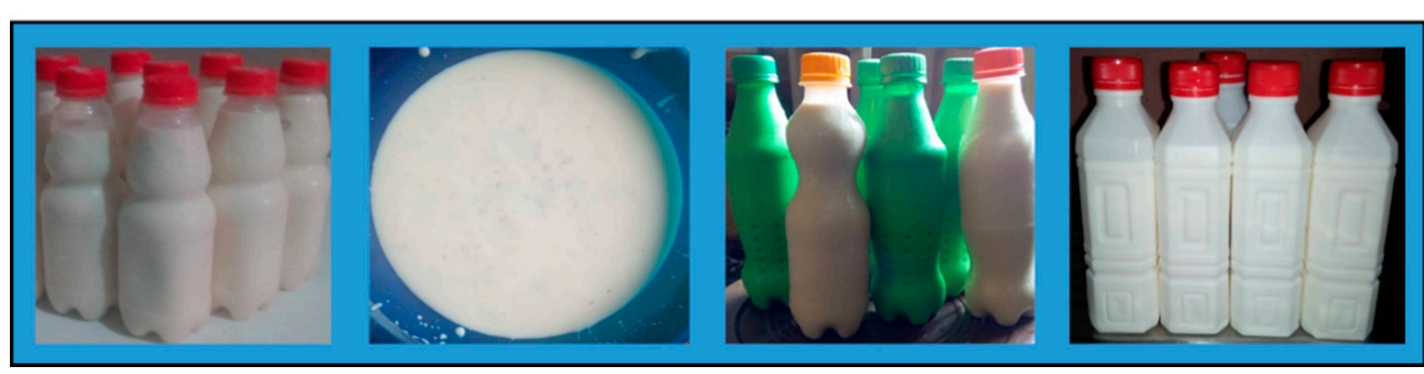

Figure 1. Traditional milk products found in Nigeria. Soymilk (A)-plant-based, nono (B) - animal-based, and tiger nut milk (C)—plant-based. The unregulated yoghurt (D) could be any type of milk.

\subsection{Plant-Based Milk Products}

\subsubsection{Soymilk}

In Nigeria, the consumption of soybeans (Glycine max) and their products, such as soymilk, has increased in the last two decades because of their high protein content (39\%) and the affordability compared to animal protein [26]. Unregulated soymilk sold in the streets of Nigeria is promoted for this reason and it currently supplements the food of many households that are not able to source enough protein from meat and poultry. Traditional home-made soymilk is normally prepared from soaked soybeans by grinding, heating, and filtering with a mesh screen to get soymilk [27]. The soymilk is then packed in sachets or plastic bottles (Figure 1A) and sold in the streets with or without regulation. Sometimes the milk is dried and sold as powders for patrons to reconstitute.

Several microbial studies [28-37] have been carried out on soymilk in Nigeria and up to 22 genera of bacteria and fungi have been identified (Table 1). For bacteria, the most prevalent genus among the studies examined was Staphylococcus whereas Aspergillus was the most prevalent fungi. Other genera found in three or more studies include Bacillus, Escherichia, Pseudomonas, Saccharomyces, Penicillin, and Rhizopus. The prevalence of Staphylococcus indicates hygiene problems whereas the presence of Aspergillus raises the issue of possible contamination with aflatoxins. Aflatoxins have been found in many species of Aspergillus [38,39] and the occurrence in both branded and unbranded soymilk 
powder [28] is a big concern. It has been reported that the soybean used for making the soymilk is likely to be the main source of Aspergillus-harbouring aflatoxins [40] and its occurrence is influenced by the method of growing, harvesting, storage and processing of crops [41].

\subsubsection{Tiger Nut Milk}

The interest in tiger nut milk (TNM) also known as Kunun-Aya, has increased over the years possibly because of its sensory, nutritional and probiotic prospects [42]. TNM (Figure 1C) beverages are made from the extract of tiger nuts. According to Sanchez-Zapata et al. [43], the tiger nut (Cyperus esculentus L.) is an edible perennial grass-like plant of tropical and Mediterranean regions with sweet almond-like tubers that are highly appreciated for their health benefits and nutritive value. Its attributes include a high content of fibre, proteins, sugars, oleic acid, glucose, phosphorus, potassium, and vitamins. The preparation of TNM has been previously described [44]. It involves removing nut nodules after which a cleaning, washing, and soaking in water for $5 \mathrm{~h}$ is then conducted. The water is drained off, followed by homogenization with a blender and then filtered with a cheesecloth to get the milk-like supernatant, which is the TNM.

Studies looking at the microorganisms in TNM have been carried out elsewhere, and Enterobacteriaceae, yeasts and moulds were detected [45]. It was concluded that there exists a rather high contamination level in home-made tiger nut beverages indicating the need to apply correct and strict hazard analysis and critical control point (HACCP) systems during manufacturing and storage. In Nigeria, many workers [46-55] have carried out a microbiological analysis on TNM and Aspergillus, Candida, and Saccharomyces were found to be the main fungal isolates, whereas Bacillus, Escherichia and Salmonella were the main bacterial isolates (Table 1). Salmonella can transmit typhoid fever and could occur from the water used for processing. The predominant fungi Aspergillus has been linked with aflatoxins in tiger nuts from Kaduna city [56] but the concentration was still within the safe limits prescribed by the national regulatory body.

\subsection{Animal-Based Milk Products}

\subsubsection{Nono}

The food drink nono in the Hausa language in northern Nigeria is the name for fermented cow milk. It is made by fermenting fresh cow milk for up to $48 \mathrm{~h}$ and then sieving to get the final product [57]. It is common to see the product hawked in the street by the so-called milkmaids. Sometimes the quantity required is measured out in bowls (Figure 1B) and then consumed straight away by the patron for instant refreshment. The proximate values of the product from different locations can vary greatly in their physicochemical and microbiological quality. The microorganisms isolated from nono, investigated in different cities [58-67], are summarised in Table 1. Overall, the bacteria genus Escherichia had the highest prevalence, followed by Staphylococcus and Klebsiella. Among the other organisms reported, the genera Enterobacter and Salmonella were detected in up to three studies. More bacteria than fungi species were reported and the most prevalent fungal genus was Candida spp.

The predominance of Escherichia spp. over the natural Lactobacillus milk organism suggests serious hygiene issues. It has been emphasised [64] that the microbiological safety of nono is not guaranteed due to unhygienic practices during production and product contamination from the vendors. The isolation rate of Escherichia varied among locations. The examination of 420 samples [62] found that $4.5 \%$ of the samples were contaminated, whereas it was $40 \%$ of 209 samples in another study [61]. Another investigation in Kaduna city [65] had 27\% of 100 samples contaminated with Escherichia. The regular occurrence of Escherichia may encourage the spread of antimicrobial resistance because some strains from nono have shown resistance to ampicillin [59]. 


\subsubsection{Yoghurt}

Yoghurt is obtained from cow milk after fermentation and may be produced at various levels of viscosity. Popular brands sold in Nigeria are sometimes watery or milk-like and can be distinguished from milk by the sour taste. Lactobacillus plays a big role in yoghurt fermentation [68] and other predominant organisms involved include Lactococcus lactis, Streptococcus thermophilus, Bifidobacterium, and Leuconostoc species [69]. Registered commercial yoghurts sold in Nigeria have a variety of physicochemical attributes and, amid the popular brands, there exists imitations or unregulated brands sold in sachets or plastic bottles (Figure 1D). These products fall short of labelling laws and the ingredients used are not known. Unregulated sales in Nigeria are rampant and these products are often sold under uncontrolled temperatures in the street.

Several investigators in the Nigerian cities of Onitsha, Kano, Keffi, Enugu, Awka, Kaduna, Abuja, and Port Harcourt have reported the microorganisms found in yoghurts sold in Nigeria [70-79]. The summary in Table 1 shows that Staphylococcus spp. is the most prevalent among the studies carried in the aforementioned cities but the organism was not isolated from a sample in the study of Kano city [70]. This emphasizes that the species is from post-process contaminations, as is generally believed, rather than a starter during yoghurt production. Other species reported in three or more studies include Escherichia, Bacillus, Streptococcus, and in particular, Lactobacillus, which is known for its role in milk fermentation for yoghurt production. The microbiological quality of the product may differ based on the good manufacturing practices of the manufacturer during and after production. To ascertain the cleanliness of a production process, a test for Escherichia is sometimes carried out. Some investigators have detected the organism in local beverage products after production [79], whereas other workers did not isolate any [71] in the samples analysed.

Up to 11 fungi genera were seen in the studies reviewed. The most prevalent was Aspergillus spp. Rhizopus, Mucor, and Saccharomyces species (Table 1). The pH modulation by fungi which enables them to secrete alkalis and acids [80] can enable them to survive during the storage of yoghurts and may have enabled several fungal species to grow because the conditions or stress environment became adaptable.

\section{Soft Drinks}

Two home-made soft drinks that are very popular in all regions and across all social strata in Nigeria are kunu and zobo. Despite its consumption by millions of people, it has yet to be properly regulated and no high volume industrial-scale production of the products has been carried out.

\section{1. Кипи}

The beverage kunu or kunu-zaki is a cheap traditional nonalcoholic fermented beverage, with a sweet-sour taste that originated from Northern Nigeria and is presently consumed across the country regardless of age [81]. The production steps for kunu have been outlined in a survey report [82]. It involves the use of millet (Pennisetum typhoideum), and most of the time sorghum (Sorghum vulgare), maize (Zea mays), rice (Oryza sativa) and ocha acha (Digitalis exilis) can also be used. In the report, it was explained that the grains can be used singly or combined. First, the grain is steeped in water for 12-72 $\mathrm{h}$, and then dry- or wet-milled with or without spices before cooking it into a thin free-flowing gruel. Further dilutions may be carried out before packing into plastic bottles (Figure 2A) for private consumption or unregulated sales to members of the public.

Some studies carried out on the product in Nigeria [83-92] show that the beverage has serious hygiene concerns because the prevalence of Escherichia species was highest in this product when compared to others reviewed (Table 1). A comparison between freshly processed and street-hawked kunu [86] showed that the fresh samples were free of coliforms whereas products found on the street were not. This shows that kunu is very susceptible to post-process contamination. The predominance of Saccharomyces (Table 1) indicates the sugar availability for fermentation and the main fungal isolates Aspergillus, Penicillium, and Fusarium suggest the possibility of mycotoxin presence. 
A $\quad$ B

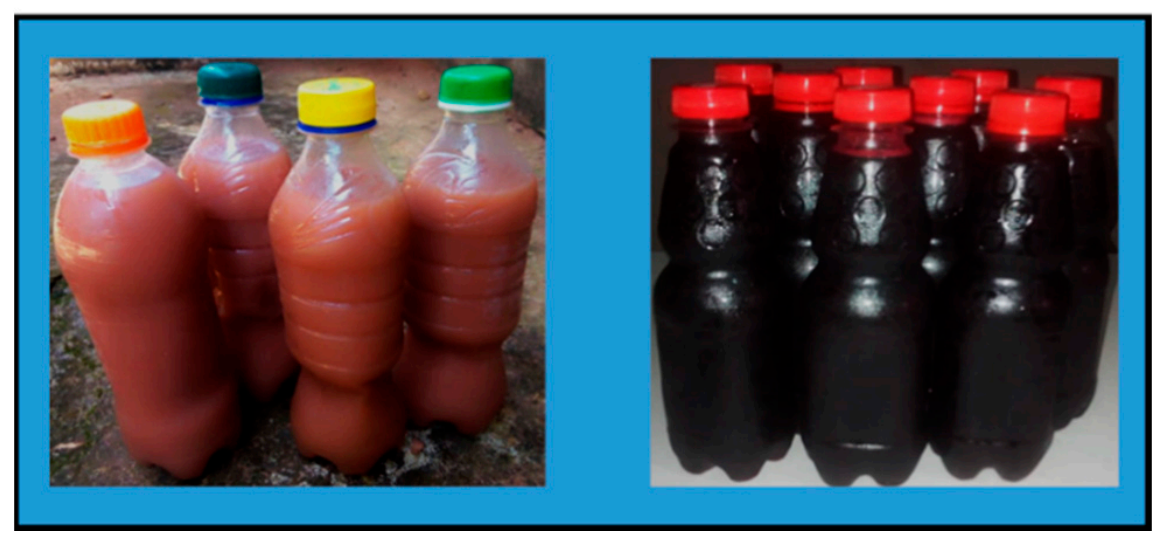

Figure 2. Popular unregulated soft drinks in Nigeria. Production of kunu (A) and zobo (B) is usually carried out from the home or other unregistered facilities.

\subsection{Zobo}

The drink zobo is one of the locally made beverages in Nigeria that is prepared from the plant Hibiscus sabdariffa [93]. The beverage is an aqueous extract with a characteristic intense red colouration [94] that is loved by many. To make the drink, calyces are washed, soaked overnight, and then boiled for $15 \mathrm{~min}$ before filtering [95]. It may be sweetened with sugar or fruit extracts for a healthier drink after which its filling into plastic bottles is carried out (Figure 2B) for private consumption or unrecorded sales.

Microbial studies [96-105] have been carried out on the product and the bacterial and fungal species prevalent are Bacillus and Penicillium among other genera. A high prevalence of Escherichia and Staphylococcus (Table 1) suggest the hygiene issues present in other beverages.

\section{Alcoholic Beverages}

\subsection{Palm Wine}

Palm wine (Figure 3A) is a milky white alcoholic drink obtained from different species of palm trees around the world. Unregulated sales are rampant in Nigeria and despite some food safety hazards associated with the drink [24], it is believed to have oenological potentials [106] and maybe be suitable as a probiotic [107] or functional beverage [108]. The drink is obtained by making incisions on the tree to collect the sap, which predisposes the drink to environmental contamination. Palm wine has a short shelf life because, after its collection from the field, the beverage undergoes a rapid microbial fermentation in a few days which yields several secondary metabolites due to microbial activity. The sale of this drink in most regions of Nigeria is vastly unregulated except for a few commercial producers that bottle and sell the product locally or internationally.

Yeasts, especially Saccharomyces, dominate palm wine among other non-Saccharomyces yeasts, bacteria and fungi and it is possibly the most studied local or traditional beverage in Nigeria for its microbial content. After the pioneering microbial work of Okafor [109], Faparusi and Bassir [110], several investigators [111-120] have reported different microbial genera from the drink in the last 10 years. There is a lower prevalence of bacteria associated with hygiene (Table 1) possibly because of the presence of ethanol, a low $\mathrm{pH}$, and the acidic conditions of the drink.

\subsection{Pito}

Pito (Figure 3B) is an artisanal alcoholic beer widely consumed in West Africa, especially in Nigeria, and it provides a source of income for many in rural areas. The beverage is made from malted sorghum or millet grains or a combination of both [121] and the production process involves malting, 
fermentation and then maturation. The beer has a very short shelf life and is normally consumed within a day after production. The bacteria and fungi associated with the drink in different Nigerian cities have been reported by several investigators [122-131]. Similar to palm wine, there was a low prevalence of hygiene organisms, which may be due to the inhibitory constituents, and the yeast Saccharomyces was the dominant genera among the fungi species in the studies reviewed (Table 1).

A

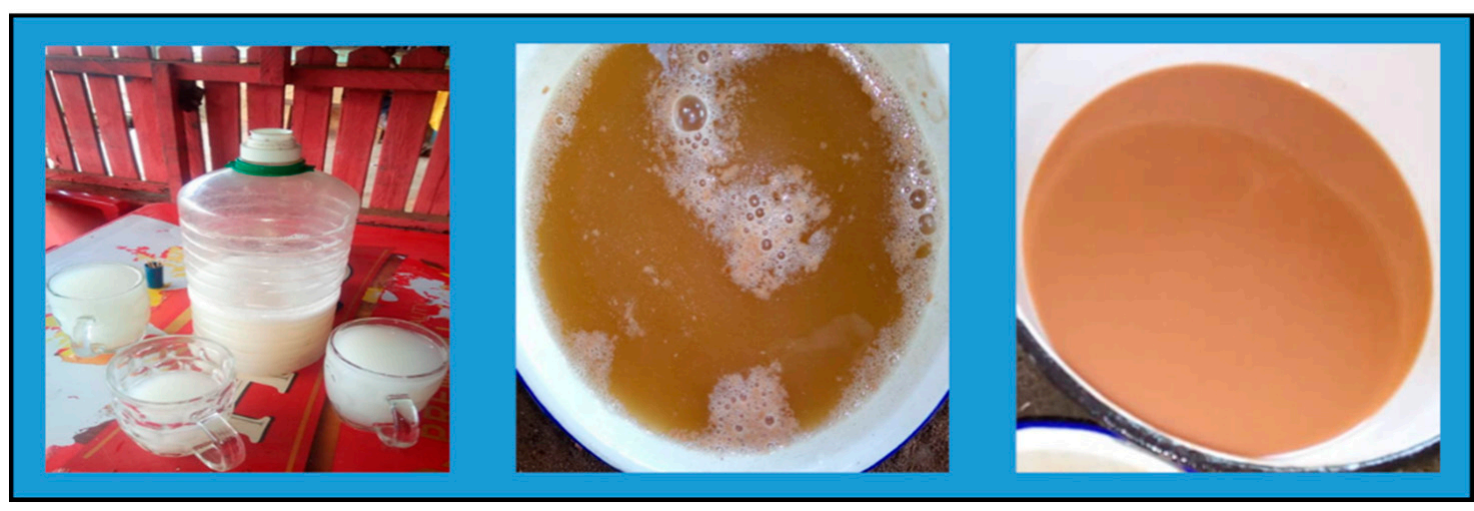

Figure 3. Three main artisanal alcoholic beverages sold in Nigeria. Palm wine (A), pito (B) and burukutu (C) are sometimes sold in makeshift open bars.

\subsection{Burukutu}

Another local beer consumed mainly in the northern and middle belt region of Nigeria is fermented burukutu. The drink is made similarly to pito, with the same materials but with slight variations in the production process [123]. Contrary to some of the aforementioned beverages, which have acceptance among all social classes, burukutu consumption is much higher among low-income earners in Nigeria. The microorganisms harboured by the drink have been characterised [132-141]. Unlike the alcoholic beverages palm wine and pito, which have a low prevalence of hygiene indicator organisms, burukutu showed a high prevalence of Escherichia and Staphylococcus among the studies reviewed (Table 1) possibly because of its physicochemical properties that allow bacteria to thrive. The prevalence of Saccharomyces is expected because of the sugar from the raw material available for fermentation. Again, Aspergillus prevalence may be a source of aflatoxins and it has been demonstrated to be present in the drink [142]. 
Table 1. Summary of the prevalence of bacteria and fungi in Nigerian beverages after an analysis of up to 90 studies. The prevalence was calculated by recording the number of times a particular genus was reported in a product.

\begin{tabular}{|c|c|c|c|c|c|c|c|c|c|c|}
\hline $\mathbf{S} / \mathbf{n}$ & Bacteria & $\begin{array}{l}\text { Yoghurt } \\
\text { [70-79] }\end{array}$ & $\begin{array}{c}\text { Nono } \\
\text { [58-67] }\end{array}$ & $\begin{array}{c}\text { Soymilk } \\
{[28-37]}\end{array}$ & $\begin{array}{c}\text { Tiger Nut Milk } \\
{[46-55]}\end{array}$ & $\begin{array}{c}\text { Zobo } \\
{[96-105]}\end{array}$ & $\begin{array}{c}\text { Kunu } \\
\text { [83-92] }\end{array}$ & $\begin{array}{c}\text { Pito } \\
\text { [123-132] }\end{array}$ & $\begin{array}{l}\text { Burukutu } \\
\text { [132-143] }\end{array}$ & $\begin{array}{l}\text { Palm Wine } \\
\text { [123-132] }\end{array}$ \\
\hline 1 & Bacillus & 5 & 2 & 4 & 6 & 8 & 7 & 2 & 5 & 4 \\
\hline 2 & Enterobacter & & 3 & 2 & 1 & 3 & 1 & & 1 & \\
\hline 3 & Escherichia & 3 & 7 & 5 & 4 & 7 & 9 & 2 & 5 & 1 \\
\hline 4 & Klebsiella & 2 & 4 & 2 & 2 & 2 & 1 & 2 & & \\
\hline 5 & Lactobacillus & 4 & 2 & 1 & 3 & 3 & 5 & 3 & 5 & 3 \\
\hline 6 & Lactococus & & & & 1 & & 1 & & 1 & \\
\hline 7 & Micrococus & 1 & & 1 & 2 & 5 & 2 & 1 & 1 & 1 \\
\hline 8 & Enterococcus & & & & 1 & & 1 & & & \\
\hline 9 & Proteus & & 2 & 1 & 2 & 3 & 1 & 1 & & \\
\hline 10 & Salmonella & & 3 & 2 & 4 & 3 & 2 & 1 & 1 & \\
\hline 11 & Shigella & & 2 & & 2 & 1 & 2 & & 1 & \\
\hline 12 & Staphylococcus & 6 & 4 & 6 & 4 & 7 & 6 & 2 & 6 & 3 \\
\hline 13 & Streptococcus & 4 & 1 & 3 & 2 & 3 & 5 & 3 & 4 & 3 \\
\hline 14 & Pediococcus & & 1 & & & & & & 1 & \\
\hline 15 & Pseudomonas & 2 & 2 & 3 & 2 & 5 & 3 & & & 1 \\
\hline 16 & Zygomonas & & & & & & & & & 1 \\
\hline 17 & Acetobacter & 1 & & & & & & 1 & 1 & \\
\hline 18 & Acinetobacter & & & & 1 & & & & & \\
\hline 19 & Citrobacter & & 1 & & 1 & & 1 & & & \\
\hline 20 & Yersinia & & 1 & & & & & & & \\
\hline 21 & Serratia & & & & 1 & 1 & & & & 1 \\
\hline 22 & Leuconostoc & & & & & & 1 & & & \\
\hline 23 & Corynebacterium & & & & & 1 & 1 & & 1 & \\
\hline 24 & Pediococcus & & & & & & 1 & & 1 & \\
\hline 25 & Flavobacterium & & & & & & & 1 & & \\
\hline 26 & Vibrio & & & & & 1 & & & & \\
\hline 27 & Veillonella & & & & & 1 & & & & \\
\hline 28 & Aeromonas & & & & & 1 & & & & \\
\hline 29 & Alcaligenes & & & & & & & 1 & & \\
\hline 30 & Listeria & & & & & & & & 1 & \\
\hline
\end{tabular}


Table 1. Cont

\begin{tabular}{|c|c|c|c|c|c|c|c|c|c|c|}
\hline$S / n$ & Bacteria & $\begin{array}{l}\text { Yoghurt } \\
{[70-79]}\end{array}$ & $\begin{array}{c}\text { Nono } \\
{[58-67]}\end{array}$ & $\begin{array}{c}\text { Soymilk } \\
{[28-37]}\end{array}$ & $\begin{array}{c}\text { Tiger Nut Milk } \\
{[46-55]}\end{array}$ & $\begin{array}{c}\text { Zobo } \\
{[96-105]}\end{array}$ & $\begin{array}{c}\text { Kunu } \\
\text { [83-92] }\end{array}$ & $\begin{array}{c}\text { Pito } \\
\text { [123-132] }\end{array}$ & $\begin{array}{l}\text { Burukutu } \\
\text { [132-143] }\end{array}$ & $\begin{array}{c}\text { Palm Wine } \\
{[123-132]}\end{array}$ \\
\hline \multicolumn{11}{|c|}{ Fungi } \\
\hline 1 & Saccharomyces & 2 & 1 & 3 & 3 & 1 & 5 & 4 & 7 & 5 \\
\hline 2 & ${ }^{*}$ Torula yeast & & & & & & 1 & & & \\
\hline 3 & Candida & 1 & 2 & 1 & 3 & 2 & 2 & 2 & 1 & 3 \\
\hline 4 & Aspergillus & 3 & 1 & 7 & 4 & 3 & 4 & 2 & 5 & 1 \\
\hline 5 & Penicillium & 1 & 1 & 3 & 2 & 4 & 4 & 1 & 1 & 1 \\
\hline 6 & Rhizopus & 2 & & 4 & 1 & 2 & 2 & 2 & 2 & \\
\hline 7 & Mucor & 2 & 1 & 1 & & 1 & 1 & 2 & 1 & \\
\hline 8 & Acremonium & 1 & & & & & & & & \\
\hline 9 & Alternaria & 1 & & 1 & & & & & & \\
\hline 10 & Fusarium & 1 & & 1 & 1 & & 3 & 1 & 1 & \\
\hline 11 & Debaryomyces & 1 & & & & & & & & \\
\hline 12 & Rhodotorula & 1 & & & & & & & & \\
\hline 13 & Cladosporium & & & 1 & & 1 & & & & \\
\hline 14 & Neosartorya & & & 1 & & & & & & \\
\hline 15 & Neurospora & & & 1 & & & & & & 1 \\
\hline 16 & Pichia & & & & 1 & & & 1 & & 2 \\
\hline 17 & Monilia & & & & & & 1 & & & \\
\hline 18 & Torulopsis & & & & & 1 & & & & \\
\hline 19 & Trichosporon & & & & & & & & & 1 \\
\hline 20 & Rhodotorula & & & & & & & 1 & & 1 \\
\hline 21 & Schizo-saccharo & & & & & & & & & 1 \\
\hline 22 & Blastomyces & & & & & & & 1 & & \\
\hline 23 & Sporotrichum & & & & & & & 1 & & \\
\hline 24 & Kluyveromyces & & & & & & & 1 & & \\
\hline 25 & Geotrichum & & 1 & & & 2 & 1 & 1 & & \\
\hline
\end{tabular}

$\mathrm{S} / \mathrm{n}=$ serial number; * Torula yeast, genus name not reported in ref [89]. Could be Candida. 


\section{Significance of Organisms Found}

\subsection{Hygiene Indicators, Pathogens and Toxic Compound Producers}

The hygiene indicators and pathogens in this section are mainly with reference to the microbial criteria outlined in the work of other investigators [143,144]. In total, 30 bacteria and 25 fungi genera (Table 1) were found in the 90 studies reviewed. The bacteria genera namely Bacillus, Escherichia, Lactobacillus, Staphylococcus, and Streptococcus were detected in all nine beverages. Additionally, only the fungi genera Saccharomyces, Aspergillus, Candida, and Penicillium were found in all the beverages. Overall, these bacterial and fungal species were the most prevalent (Figure 4).

It is worrying that the three most prevalent bacteria (Figure 4A) are Bacillus, Escherichia, and Staphylococcus. These species are known hygiene indicators and suggest very poor hygienic conditions during the preparation and storage of beverages. In particular, the roles of Escherichia and other Enterobacteriaceae as hygiene markers are well-reported [143] and high counts of these species mean that the food or drink did not follow normal food safety procedures. The concern is that the hygiene indicator organisms could also be pathogenic. Most of the studies reviewed declared the beverage unsafe once hygiene indicator organisms were detected without any further tests for pathogenicity. There were no tests to confirm whether the Bacillus species observed were pathogenic B. cereus or B. subtilis, which could have probiotic potential. Additionally, a confirmation assay to determine if the E. coli strain found was the shiga toxin-producing E. coli O157:H7 or other E. coli serotypes with pathogenic potential was not carried out. The yoghurt and nono Staphylococcus strains have been found to harbour the mecA gene [145] that encodes methicillin resistance but, in most cases, the isolates were not probed to determine if they are methicillin-resistant strains. It has been reported that the microorganisms associated with unhygienic processing conditions are mainly environmental contaminants with a few of faecal origin [146]. Hence, it can be concluded that most of the indicator organisms found in the studies reviewed were due to process contamination and they may not be pathogenic strains.

The most prevalent yeasts are the genus Saccharomyces and Candida (Figure 4A). The dominance of Saccharomyces is expected because it is known as a dominant organism in many beverage fermentations. There are no immediate concerns for adverse toxic metabolites from Saccharomyces fermentation but the risk could exist due to methanol production when the product is distilled into gin [23]. Some clinical strains of Candida have been implicated in many infections even though many nonpathogenic strains are part of the environmental flora. The occurrence of three fungal genera, namely Aspergillus, Penicillium and Fusarium, which are responsible for producing the majority of the mycotoxins that are toxic to humans, animals and plants [147] may mean that post-production tests of the beverages are required to assure food safety.

\subsection{Molecular Characterization}

Since $99 \%$ of species level identifications in the papers reviewed were based on classical biochemical methods only, it may be erroneous to report to the species level. In line with current taxonomy methods, it is important that reclassification based on molecular methods is carried out in order to obtain the actual species associated with the beverages reported. The problem regarding the resources required to perform molecular characterizations contributed to the minimal investigation of the pathogenicity of microorganisms isolated in the beverages reviewed. For some of the beverages, such as pito, studies on the molecular characterisation of organisms in the product are rare in the literature. In most studies where a molecular identification was carried out, it was facilitated by the collaboration with other laboratories outside of the country. These collaborations are desirable because they have led to the sequencing and discovery of novel new species or actual strains involved in the fermentation of some beverages. Different yeasts [148,149] and bacteria [150] species have been identified in palm wine and specific Lactobacillus strains have been found [151] in nono after its molecular characterization. 


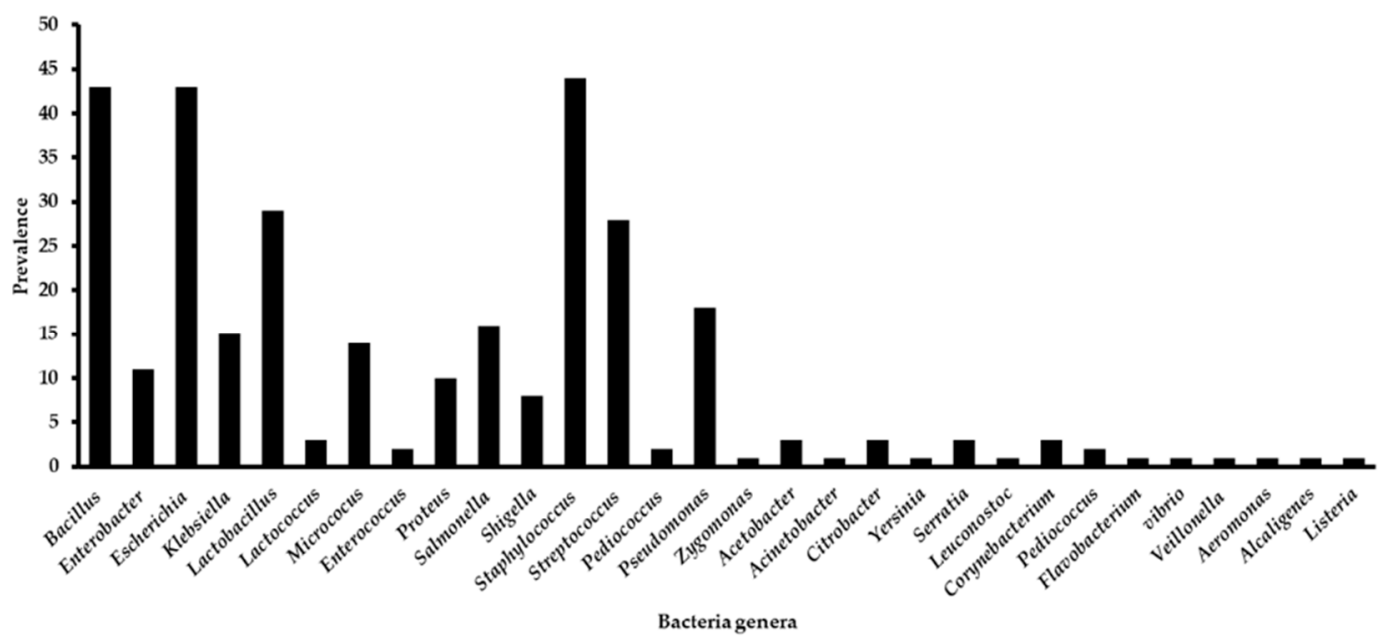

(A)

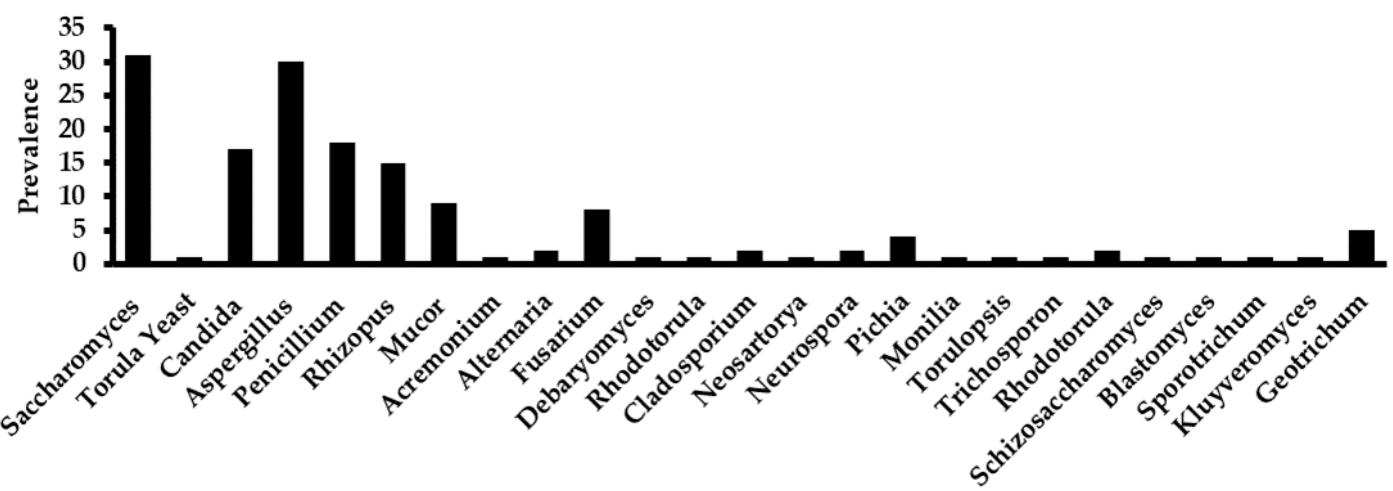

Yeast genera

(B)

Figure 4. Summary of 30 bacteria (A) and 25 yeast (B) genera associated with nine local beverages reported in 90 articles. The most commonly reported species for bacteria, yeast and filamentous fungi are Staphylococcus, Saccharomyces and Aspergillus, respectively. Overall prevalence was calculated as the actual number of times a genus was isolated across the 90 studies.

To help understand the microbial populations of these products and to design specific starter cultures and manufacture safer foods, Ezekiel et al. [152] used a high-throughput sequence analysis to investigate the bacterial communities in kunu and found potential human enteric pathogens and other organisms not associated with kunu processing. In another metagenomics study [153] of Nigerian and other African beverages, dominant species were highlighted and it was found that lactobacilli were less abundant in fermentations performed under laboratory conditions when compared to artisanal or commercial fermentations.

\subsection{Practical Implications of the Genera Found in Beverages}

Three out of the nine genera found in all beverages (Section 5.1), namely Bacillus, Escherichia and Staphylococcus, are well known for foodborne outbreaks which can occur due to post-process contamination. The screening of foods for the prevalence of these bacterial species, in particular Bacillus cereus, Escherichia coli, and Staphylococcus aureus, is always expected to be carried out in line with national or regional regulations. For fungi, most isolates originate from the raw material used for making the beverage and they are often isolated during spoilage, hence they are not discussed in this section. 


\subsubsection{Bacillus}

According to Cote et al. [154], the genus Bacillus has over 260 species and is a diverse group of spore-forming bacteria responsible for food poisoning resulting in diarrheal syndromes. These syndromes are suspected to be caused by the various cytotoxins and degradative enzymes produced by bacteria under the control of the virulence regulator PlcR. However, it has been highlighted that most strains that produce these factors are not generally pathogenic. Species regarded as nonpathogenic include B. thuringiensis strains that are used as biopesticides [155] and B. coagulans, which have been reported [156] to promote intestinal digestion, inhibit the growth of pathogenic bacteria and normalize immune cells. Contrastingly, the species Bacillus cereus forms spores, biofilms, emetic toxins and causes diarrhoea [157]. It can also produce cereulide, a potent toxin which is highly heat- and acid-resistant [158]. The median Bacillus cereus outbreak incubation periods have been reported to be up to $4 \mathrm{~h}$ in a study that covered 16 years [159], but knowledge of the mechanistic basis of spore germination and outgrowth is still a difficult challenge [160]. In some countries, Bacillus cereus has been proposed as the main causal agent of foodborne outbreaks [161] and outbreaks around the world are still common especially after celebration parties [162] and in schools, as exemplified in previous reports [163-165]. The proper identification of the Bacillus species in a beverage from a region or location will ensure a targeted and effective control.

\subsubsection{Escherichia}

The organisms in the genus Escherichia are well known enteric pathogens. One of the species E. coli $\mathrm{O} 157: \mathrm{H7}$, is one of the most dangerous foodborne pathogenic bacteria around the world [166]. Some species harbour extended-spectrum $\beta$-lactamase and cause multidrug resistance which is influenced by various factors such as environmental sources, and international travel [167] and this may be why the most frequent route of transmission for E. coli O157:H7 infections is through the consumption of contaminated food and water [168]. A proposed primary prevention strategy in developing countries and for travelers to these regions is the continuous development of new vaccines [169]. Foodborne disease outbreaks due to the presence of E. coli toxins in food is common [170] and the aetiology of some shiga toxin E. coli strains has been reported to be up to $87 \mathrm{~h}$ [154], which may be helpful for medical interventions when it is suspected that it has been ingested. The implications of persistent foodborne diarrheagenic E. coli in the agricultural and food production environment for food safety and public health has been reviewed. It was highlighted that bacterial processes such as initial attachment, biofilm formation, horizontal gene transfer and responses to environmental stresses enable the emergence of potentially more virulent strains within the agricultural and food production environment [171].

\subsubsection{Staphylococcus}

Staphylococcus is widely distributed in nature and is a part of normal flora among humans, animals, plants and the environment, hence the possibility of food contamination with the genus is very high. A huge concern in the last couple of decades is the prevalence of methicillin-resistant Staphylococcus aureus (MRSA). These strains were first reported in humans in the 1960s as important nosocomial pathogens, and subsequently emerged in food-initiated MRSA outbreaks [172]. Similar to Bacillus, the median outbreak incubation period is believed to be up to $4 \mathrm{~h}$ [159]. The presence of MRSA in the food chain has implications for food safety and surveillance programs are required for rapid MRSA detection and control [173]. Use of a state-of-the-art biosensor method for the detection and quantification of S. aureus is increasingly becoming popular [174], and a preventive control approach may include the removal of Staphylococcal biofilms which serve as a virulence factor, allowing MRSA strains to adhere to surfaces and other materials used in the food industry [172]. An improved understanding of household transmission dynamics and the relationship between the transmission in healthcare and household settings [175], where food and beverages are consumed, is important in the control of MRSA. 


\subsubsection{Positive Aspects of Beverage Fermentation}

Issues associated with the organisms detected due to poor hygiene or the presence of the organism in the beverage fermentation process can be positive and not only negative, as mentioned above. Processes such as adding lactic acid bacteria as a probiotic during fermentation have been shown to acidify tiger nut milk and reduce the growth of undesirable microrganisms [176]. Another probiotic bacteria is Bacillus coagulans whose genetic model has been proposed [177] for use in the evaluation of risk-related gene traits, combining a whole genome sequencing analysis with updated bioinformatics tools and standard phenotypic assays. The local beverages can be screened for this organism and the model can be used to establish the safety of all bacteria found in traditional beverages. Other fungi, such as Aspergillus oryzae, can produce fungal biomass for feed, fatty acids and glycerol from fat-rich dairy substrates [178]. This suggests that wastes from the local beverage productions can be valourised for new product development. Sometimes products can be improved by the co-inoculation of some genera mentioned in this study. Tufariello et al. [179] found that a multistarter formulation using Candida zemplinina, Saccharomyces cerevisiae and Lactobacillus plantarum for industrial wine production was able to enhance the organoleptic wine features to different extents. It would be interesting to examine the effect of co-inoculating these organisms in the aforementioned local beverages.

Another concern for beverage fermentation is the production of bioamines, which can be good or not beneficial. According to previous reports [180,181], biogenic amines can be found in all foods containing proteins or free amino acids and are found in a wide range of fermented and nonfermented food products. The reports also highlighted that they play an important role as a source of nitrogen and precursor for the synthesis of hormones, alkaloids, nucleic acids, proteins, amines and food aroma components. In contrast, it was pointed out that food containing high amounts of biogenic amines may have toxicological effects.

\section{Future Perspectives}

There are many "farm to cup" opportunities for more microbiological studies in several aspects of the beverages mentioned in this review. The dominant species that occur at each stage of the production process and storage needs to be determined with molecular methods. Data on the mechanism of the formation and types of secondary metabolites associated with fermentation are critical for public health and would be beneficial if obtained. Furthermore, folklore health claims for the products from the microbial fermentation of the beverages needs further investigation. The regulation for the production and sales of these traditional beverages needs standardization with set production thresholds. Additionally, basic food safety training and licensing for producers and sellers should be compulsory. The costs of these must be very affordable or subsidized and training materials in the language of the person concerned may be used.

Author Contributions: Conceptualization, O.N.; methodology, O.N., C.C.A., V.C.I., C.E.S. and M.U.U.; formal analysis, O.N., C.C.A., V.C.I., C.E.S. and M.U.U.; resources, O.N., C.C.A., V.C.I., C.E.S. and M.U.U.; data curation, O.N.; writing-original draft preparation, O.N., C.C.A., V.C.I., C.E.S. and M.U.U.; writing-review and editing, O.N. and M.U.U.; project administration, C.C.A. All authors have read and agreed to the submitted version of the manuscript.

Funding: This research received no external funding.

Conflicts of Interest: The authors declare no conflict of interest.

\section{References}

1. Okaru, A.O.; Rehm, J.; Sommerfeld, K.; Kuballa, T.; Walch, S.G.; Lachenmeier, D.W. The threat to quality of alcoholic beverages by unrecorded consumption. In Alcoholic Beverages, 7th ed.; Grumezescu, A.M., Holban, A.M., Eds.; Woodhead Publishing (Elsevier): Kidlington, UK, 2019; pp. 1-34.

2. Kamiloglu, S. Authenticity and traceability in beverages. Food Chem. 2019, 277, 12-24. [CrossRef] [PubMed] 
3. De Sanctis, V.; Soliman, N.; Soliman, A.T.; Elsedjy, H.; di Maio, S.; Kholy, M.; Piscina, B. Caffeinated energy drink consumption among adolescents and potential health consequences associated with their use: A significant public health hazard. Acta Biomed. 2017, 88, 222-231. [PubMed]

4. Cífková, R.; Krajčoviechová, A. Alcohol and cardiovascular disease: Position paper of the Czech Society of Cardiology. Cent. Eur. J. Publ. Health 2019, 27, S6-S9. [CrossRef] [PubMed]

5. Ayoub-Charette, S.; Liu, Q.; Khan, T.A.; Au-Yeung, F.; Mejia, S.B.; de Souza, R.J.; Wolever, T.M.; Leiter, L.A.; Kendall, C.; Sievenpiper, J.L. Important food sources of fructose-containing sugars and incident gout: A systematic review and meta-analysis of prospective cohort studies. BMJ Open 2019, 9, e024171. [CrossRef] [PubMed]

6. Collin, L.J.; Judd, S.; Safford, M.; Vaccarino, V.; Welsh, J.A. Association of sugary beverage consumption with mortality risk in US Adults: A secondary analysis of data from the REGARDS Study. JAMA Netw. Open 2019, 2, e193121. [CrossRef]

7. Tamang, J.P.; Watanabe, K.; Holzapfel, W.H. Diversity of Microorganisms in Global Fermented Foods and Beverages. Front. Microbiol. 2016, 7, 377. Available online: https://www.frontiersin.org/article/10.3389/fmicb. 2016.00377 (accessed on 2 July 2020). [CrossRef]

8. Capozzi, V.; Fragasso, M.; Romaniello, R.; Berbegal, C.; Russo, P.; Spano, G. Spontaneous Food Fermentations and Potential Risks for Human Health. Fermentation 2017, 3, 49. [CrossRef]

9. Cocolin, L.; Gobbetti, M.; Neviani, E.; Daffonchio, D. Ensuring safety in artisanal food microbiology. Nat. Microbiol. 2016, 1, 16171. Available online: https://www.nature.com/articles/nmicrobiol2016171 (accessed on 4 July 2020). [CrossRef]

10. Adams, M.; Mitchell, R. Fermentation and pathogen control: A risk assessment approach. Int. J. Food Microbiol. 2002, 79, 75-83. [CrossRef]

11. Capozzi, V.; Fragasso, M.; Russo, P. Microbiological Safety and the Management of Microbial Resources in Artisanal Foods and Beverages: The Need for a Transdisciplinary Assessment to Conciliate Actual Trends and Risks Avoidance. Microorganisms 2020, 8, 306. [CrossRef]

12. Nwaiwu, O. Use of fragments from D1/D2 Domain of 26S rRNA gene to select Saccharomyces cerevisiae from palm wine. J. Appl. Life Sci. Int. 2016, 5, 1-5. [CrossRef]

13. Florence, A.A.; Courage, K.S.S.; Francis, K.A.; Hellie, G. Shelf life improvement of sorghum beer (Pito) through the addition of Moringa oleifera and pasteurization. Afr. J. Biotechnol. 2016, 15, 2627-2636. [CrossRef]

14. Okiki, P.A.; Adeniji, C.A.; Oyetunji, O.A.; Yusuf, O.A.; Peters, O.A. Assessment of the physicochemical and bacteriological qualities of Nono-A fermented cow milk. Potravinarstvo 2018, 12, 26-32. [CrossRef]

15. Ani, E.; Amove, J.; Igbabul, B. Physicochemical, Microbiological, sensory properties and storage stability of plant-based yoghurt produced from Bambaranut, soybean and Moringa oleifera seed milks. Am. J. Food Nutr. 2018, 6, 115-125.

16. Ajiboye, T.O.; Iliasu, G.A.; Ojewuyi, O.B.; Abdulazeez, A.T.; Muhammed, A.O.; Kolawole, F.L. Sorghum-based alcoholic beverage, Burukutu, perturbs the redox status of the liver of male rats. Food Sci. Nutr. 2014, 2, 591-596. [CrossRef]

17. Ukwuru, M.U.; Ogbodo, A.C. Effect of processing treatment on the quality of tigernut milk. Pakistan J. Nutr. 2011, 10, 95-100. [CrossRef]

18. Ozoh, C.N.; Umeaku, C.N. Public health implication of ready-to drink soymilk and soymilk yogurt sold in Onitsha Urban Anambra State, Nigeria. J. Multidiscip. Eng. Sci. Technol. 2016, 3, 5386-5393.

19. Adelekan, A.O.; Alamu, A.E.; Arisa, N.U.; Adebayo, Y.O.; Dosa, A.S. Nutritional, microbiological and sensory characteristics of malted soy-kunu zaki: An improved traditional beverage. Adv. Microbiol. 2013, 3, 389-397. [CrossRef]

20. Izah, C.S.; Kigigha, L.T.; Aseibai, R.E.; Okowa, P.I.; Orutugu, L.A. Advances in preservatives and condiments used in Zobo (a food-drink) production. Biotechnol. Res. 2016, 2, 104-119.

21. Omoleke, S.A.; Ajibola, O.; Ajiboye, J.O.; Raji, R.O. Quagmire of epidemic disease outbreaks reporting in Nigeria. BMJ Glob. Health 2018, 3. [CrossRef]

22. WHO. Global Status Report on Alcohol and Health 2018; World Health Organization: Geneva, Switzerland, 2018; Available online: https://www.who.int/substance_abuse/publications/global_alcohol_report/en/ (accessed on 25 January 2020).

23. Ohimain, E.I. Methanol contamination in traditionally fermented alcoholic beverages: The microbial dimension. SpringerPlus 2016, 5, 1607. [CrossRef] [PubMed] 
24. Nwaiwu, O.; Itumoh, M. Chemical contaminants associated with palm wine from Nigeria are potential food safety hazards. Beverages 2017, 3, 16. [CrossRef]

25. Raji, M.I.O.; Jiya, M.H. Evaluation of pathogenic bacteria in packaged milk products sold in Sokoto metropolis, Nigeria. Asian J. Appl. Sci. 2019, 12, 85-90. [CrossRef]

26. Ukwuru, M.U.; Adama, A. Chemical evaluation and storage stability of a beverage formulated from soybean and papaya pulp flour blends. Plant Foods Hum. Nutr. 2003, 58, 1-11. [CrossRef]

27. Jiang, S.; Cai, W.; Xu, B. Food Quality improvement of soy milk made from short-time germinated soybeans. Foods 2013, 2, 198-212. [CrossRef] [PubMed]

28. Adebayo-Tayo, B.C.; Adegoke, A.A.; Akinjogunla, O.J. Microbial and physico-chemical quality of powdered soymilk samples in Akwa Ibom, South Southern Nigeria. Afr. J. Biotechnol. 2009, 8, 3066-3071.

29. Liamngee, K.; Terna, T.P.; Bem, A.A.; Orpin, J.B.; Mzungu, I.; Obaje, M.; Anum, T. Microbial analysis of soyabean milk sold in Makurdi metropolis. IOSR J. Environ. Sci. Toxicol. Food Technol. 2013, 3, 97-104. [CrossRef]

30. Adeleke, O.E.; Adeniyi, B.A.; Akinrinmisi, A.A. Microbiological quality of local soymilk: A public health appraisal. Afr. J. Biomed. Res. 2000, 3, 89-92.

31. Agboke, A.A.; Osonwa, U.E.; Opurum, C.C.; Ibezim, E.C. Evaluation of microbiology quality of some soybean milk products consumed in Nigeria. Pharmacologia 2012, 3, 513-518. [CrossRef]

32. Anagu, L.; Okolocha, E.; Ikegbunam, M.; Ugwu, M.; Oli, A.; Esimone, C. Potential spread of pathogens by consumption of locally produced Zobo and soya milk drinks in Awka metropolis, Nigeria. Br. Microbiol. Res. J. 2015, 5, 424-431. [CrossRef]

33. Brooks, A.A.; Asamudo, N.U.; Udoukpo, F.C. Microbiological and physico-chemical analysis of soymilk and soy flour sold in Uyo metropolis, Nigeria. Glob. J. Pure Appl. Sci. 2003, 9, 457-463.

34. Ezekiel, C.N.; Fapohunda, S.O. Mycological and nutrient profile of soymilk. Glob. Adv. Res. J. Food Sci. Technol. 2012, 2, 025-030.

35. Agwa, O.K.; Ossai-Chidi, L.N. Surveillance of the microbial quality of soybean products sold within markets in Port Harcourt metropolis, Rivers State, Nigeria. Food Public Health 2016, 6, 130-139. Available online: http://article.sapub.org/10.5923.j.fph.20160605.04.html (accessed on 16 July 2020).

36. Mbajiuka, C.S.; Obeagu, E.I.; Ifediora, A.C.; Ugwu, G.U. Isolation and identification of microorganisms involved in the spoilage of soymilk. IOSR J. Pharm. Biol. Sci. 2014, 9, 29-36.

37. Akani, N.P.; Barika, P.N. Fungi associated with soymilk during storage. Niger. J. Mycol. 2019, 11, $93-101$.

38. Carvajal-Campos, A.; Manizan, A.; Tadrist, S.; Akaki, D.; Koffi-Nevry, R.; Moore, G.; Fapohunda, S.; Bailly, S.; Montet, D.; Oswald, I.; et al. Aspergillus korhogoensis, a novel aflatoxin producing species from the Côte d'Ivoire. Toxins 2017, 9, 353. [CrossRef]

39. Chang, P.K.; Scharfenstein, L.L.; Luo, M.; Mahoney, N.; Molyneux, R.J.; Yu, J.; Brown, R.L.; Campbell, B.C. Loss of MsnA, a putative stress regulatory gene, in Aspergillus parasiticus and Aspergillus flavus increased production of conidia, aflatoxins and Kojic Acid. Toxins 2011, 3, 82-104. [CrossRef]

40. Ahmed Abdullah Murshed, S.; Bacha, N.; Alharazi, T. Detection of total aflatoxins in groundnut and soybean samples in Yemen using enzyme-linked immunosorbent assay. J. Food Qual. 2019, 2019, 1614502. [CrossRef]

41. Pitt, J.I.; Taniwaki, M.H.; Cole, M.B. Mycotoxin production in major crops as influenced by growing, harvesting, storage and processing, with emphasis on the achievement of food safety objectives. Food Control 2013, 32, 205-215. [CrossRef]

42. Kizzie-Hayford, N.; Jaros, D.; Zahn, S.; Rohm, H. Effects of protein enrichment on the microbiological, physicochemical and sensory properties of fermented tiger nut milk. LWT Food Sci. Technol. 2016, 74, 319-324. [CrossRef]

43. Sánchez-Zapata, E.; Fernández-López, J.; Angel Pérez-Alvarez, J. Tiger nut (Cyperus Esculentus) Commercialization: Health aspects, composition, properties, and food applications. Compr. Rev. Food Sci. Food Saf. 2012, 11, 366-377. [CrossRef]

44. Akoma, O.; Elekwa, U.O.; Afodurinbi, T.T.; Onyeukwu, G.C. Yoghurt from Coconut and Tigernuts. J. Food Technol. Afr. 2000, 5, 132-134. Available online: https://www.ajol.info/index.php/jfta/article/view/19270 (accessed on 13 July 2020).

45. Sebastià, N.; El-Shenawy, M.; Mañes, J.; Soriano, J.M. Assessment of microbial quality of commercial and home-made tiger-nut beverages. Lett. Appl. Microbiol. 2012, 54, 299-305. [CrossRef] 
46. Onovo, J.C.; Ogaraku, A.O. Studies on some microorganisms associated with exposed tiger nut (Cyperus esculentus) milk. J. Biol. Sci. 2007, 7, 1548-1550.

47. Okorie, S.U.; Adedokun, I.; Duru, N. Effect of blending and storage conditions on the microbial quality and sensory characteristics of soy-tiger nut milk beverage. Food Sci. Qual. Manag. 2014, 31, 96-103. Available online: https://iiste.org/Journals/index.php/FSQM/article/view/15581 (accessed on 16 July 2020).

48. Ogbodo, A.C.; Agwaranze, D.I.; Nwaneri, C.B.; Yakubu, M.N.; Hussaini, Z.J. Comparative Study on the Bacteriological Quality of Kunun-Aya sold in Wukari, Nigeria. Int. J. Res. Stud. Microbiol. Biotechnol. 2018, 4, 23-29. [CrossRef]

49. Badua, M.H.; Bilyaminu, D.; Ogori, A.F.; Charles, B.; Ogori, J. Microbial quality evaluation of tiger nut beverage (Kunun Aya) processed sold in University of Maiduguri. EC Nutr. 2018, 13, 138-142. Available online: https://www.ecronicon.com/ecnu/pdf/ECNU-13-00439.pdf (accessed on 16 July 2020).

50. Maduka, N. Molecular characterization of non-lactic bacteria in lactic fermented tigernut-milk drink and effect of ambient and refrigeration temperature storage on sensory properties of the drink spiced with ginger and garlic. Microbiol. Res. J. Int. 2017, 22, 1-11. [CrossRef]

51. Shu'aibu, I.; Hadiza, J.A.; Yusha'u, M.; Kabiru, M.Y.; Ahmad, M.M.; Lawal, G.; Adamu, M.T.; Khairiyya, M. Assessment of foods and drinks for the presence of extended spectrum beta lactamase (ESBL) producing bacteria in Gombe metropolis, Nigeria. Indian J. Sci. Technol. 2016, 9. [CrossRef]

52. Umar, Z.D.; Bashir, A.; Raubilu, S.A. Study on bacteriological quality of kunun aya (tigernut juice) sold at Umaru Musa Yar'adua university (UMYU) campus, Katsina. Int. J. Environ. 2014, 3, 87-97. [CrossRef]

53. Osho, M.B.; Shobande, O.E. Microbiological assessment of tiger nut milk as a potential probiotic product. Niger. J. Biotechnol. 2019, 36, 186-193. [CrossRef]

54. Wakil, S.M.; Ayenuro, O.T.; Oyinlola, K.A. Microbiological and nutritional assessment of starter-developed fermented tigernut milk. Food Nutr. Sci. 2014, 5, 495-506. [CrossRef]

55. Udeozor, L.O.; Awonorin, S.O. Comparative microbial analysis and storage of tigernut-soy milk extract. Austin J. Food Nutri. Sci. 2014, 2, 1026.

56. Shamsuddeen, U.; Aminu, H.A. Occurrence of aflatoxin in Cyperus esculentus (Tiger Nut) sold and consumed raw in Kaduna. Int. J. Sci. Res. Educ. 2016, 4, 5189-5195. Available online: http://ijsae.in/ijsaeems/index.php/ ijsae/article/view/1189 (accessed on 16 July 2020). [CrossRef]

57. Bankole, M.O.; Okagbue, R.N. Properties of "Nono," a Nigerian fermented milk food. Ecol. Food Nutr. 1992, 27, 145-149. [CrossRef]

58. Anyanwu, N.C.J.S. Microbiological and comparative analysis of indigenous and semi-industrial fermented milk drinks (Fura Da Nono and Fura Da Yoghurt) sold in Nigeria's capital. Int. J. Bioassays 2019, 8, 5716-5723.

59. Olasupo, N.A.; Smith, S.I.; Akinsinde, K.A. Examination of the microbial status of selected indigenous fermented foods in Nigeria. J. Food Saf. 2002, 22, 85-93. [CrossRef]

60. Yabaya, A.; Manga, S.S.; Lucy, M.; Alhassan, H.M. Bacteriological quality of fermented milk sold locally in Samaru and Sabongari market, Zaria-Nigeria. Cont. J. Microbiol. 2012, 6, 14-18. Available online: https://zenodo.org/record/824031\#.XxDWkShKjIU (accessed on 16 July 2020).

61. Okonkwo, O.I. Microbial analysis and safety evaluation of Nono: A fermented milk product consumed in most part of Northern Nigeria. Int. J. Dairy Sci. 2011, 6, 181-189.

62. Reuben, R.C.; Owuna, G. Antimicrobial resistance patterns of Escherichia coli 0157:H7 from Nigerian fermented milk samples in Nasarawa state, Nigeria. Int. J. Pharm. Sci. Invent. 2013, 2, 38-44.

63. Obi, C.N.; Ikenebomeh, M.J. Studies on the microbiology and nutritional qualities of a Nigerian fermented milk product (Nono). Int. J. Dairy Sci. 2007, 2, 95-99.

64. Dafur, G.S.; Iheukwumere, C.C.; Azua, E.T.; Dafur, B.S. Evaluation of the Microbial Quality of 'Nono' Sold in Mangu Local Government Area of Plateau State, Nigeria. Available online: https:/www.journalsajrm.com/ index.php/SAJRM/article/view/29245 (accessed on 16 July 2020).

65. Maikai, B.V.; Madaki, P.D. Enumeration of coliforms in fermented milk product (Nono) sold in Samaru, Kaduna State, Nigeria. Sokoto J. Vet. Sci. 2019, 16, 50-57. [CrossRef]

66. Vantsawa, P.A.; Maryah, U.T.; Bulus, T. Isolation and identification of lactic acid bacteria with probiotic potential from fermented cow milk (Nono) in Unguwar Rimi, Kaduna State Nigeria. Am. J. Mol. Biol. 2017, 7, 99-106. [CrossRef]

67. Belewu, O.A.; Aina, O.S. Microbial evaluation of indigenous milk products with special reference to the bacteria flora of some public health importance in Nigeria. Afr. J. Clin. Exp. Microbiol. 2000, 1, 13-19. 
68. Mani-López, E.; Palou, E.; López-Malo, A. Probiotic viability and storage stability of yogurts and fermented milks prepared with several mixtures of lactic acid bacteria. J. Dairy Sci. 2014, 97, 2578-2590. [CrossRef] [PubMed]

69. Chen, C.; Zhao, S.; Hao, G.; Yu, H.; Tian, H.; Zhao, G. Role of Lactic Acid Bacteria on the Yogurt Flavour: A Review. Int. J. Food Prop. 2017, 20, S316-S330. [CrossRef]

70. Omola, E.; Kawo, A.; Shamsudden, U. Physico-Chemical, sensory and microbiological qualities of yoghurt brands sold in kano metropolis, Nigeria. Bayero J. Pure Appl. Sci. 2015, 7, 26-30. [CrossRef]

71. Nwagu, T.N.; Amadi, E.C.; Tochukwu Nwamaka, N.; Chike, A.E. Bacteria population of some commercially prepared yoghurt sold in Enugu State, Eastern Nigeria. Afr. J. Microbiol. Res. 2010, 4, 984-988.

72. Makut, M.D.; Ogbonna, A.I.; Dalami, H. An Assessment of the Bacteriological Quality of Different Brands of Yoghurt Sold in Keffi, Nasarawa State, Nigeria. J. Nat. Sci. Res. 2014, 4, 19-22.

73. Agu, K.C.; Archibong, E.J.; Anekwe, D.C.; Ago, C.A.; Okafor, A.C.; Awah, N.S. Assessment of bacteria present in yoghurt sold on Awka metropolis. Sch. J. Appl. Med. Sci. 2014, 2, 3071-3075.

74. De, N.; Goodluck, T.M.; Bobai, M. Microbiological quality assessment of bottled yogurt of different brands sold in Central Market, Kaduna Metropolis, Kaduna, Nigeria. Int. J. Curr. Microbiol. Appl. Sci. 2014, 3, $20-27$.

75. Dirisu, C.G.; Lily, G.; Igwe, E. Microbiological load of yoghurt sold in Omoku schools, Rivers State, Nigeria. Afr. J. Microbiol. Res. 2015, 9, 1960-1963.

76. Mepba, H.D.; Achinewhu, S.C.; Aso, S.N.; Wachukwu, C.K. Microbiological quality of selected street foods in Port Harcourt, Nigeria. J. Food Saf. 2007, 27, 208-218. [CrossRef]

77. Aguoru, C.U.; Dania, G.V. Microbiological examination of commercial probiotic yoghurt produced and sold in Makurdi, Benue state, Nigeria. Int. Sci. Res. J. 2010, 2, 52-55. Available online: http://www.academicpublications.org/isrj/Microbiological_Examination_Aguoru_Dania_52-55.pdf (accessed on 16 July 2020).

78. Obire, O.; Berembo, B.T. Microorganisms associated with street vended yoghurt in mile 1 Diobu area of Port Harcourt, Nigeria. J. Sci. Technol. 2014, 5, 179-186. Available online: http://ejournals.teiath.gr/index.php/ejst/ article/view/812 (accessed on 16 July 2020).

79. Ifeanyi, V.O.; Ihesiaba, E.O.; Muomaife, O.M.; Ikenga, C. Assessment of microbiological quality of yogurt sold by street vendors in Onitsha metropolis, Anambra state, Nigeria. Br. Microbiol. Res. J. 2013, 3, 198-205. [CrossRef]

80. Vylkova, S. Environmental $\mathrm{pH}$ modulation by pathogenic fungi as a strategy to conquer the host. PLOS Pathog. 2017, 13, e1006149. [CrossRef]

81. Bede, E.N.; Okeke, C.E.; Amandikwa, C. Physicochemical properties and sensory evaluation of Kunu-Zaki beverage produced by substitution of sweet potatoes with date fruits. IOSR J. Environ. Sci. Toxicol. Food. Technol. 2015, 9, 81-84.

82. Gaffa, T.; Jideani, I.A.; Nkama, I. Traditional production, consumption and storage of Kunu-a non alcoholic cereal beverage. Plant Foods Hum. Nutr. 2002, 57, 73-81. [CrossRef]

83. Mbachu, A.E.; Etok, C.A.; Agu, K.C.; Okafor, O.I.; Awah, N.S.; Chidi-Onuorah, L.C.; Ekwueme, V.C.; Okpala, J.; Ogbue, M.O.; Ikele, M.O. Microbial quality of Kunu drink sold in Calabar, Cross River state, Nigeria. J. Glob. Biosci. 2014, 3, 511-515. Available online: https://pdfs.semanticscholar.org/ ce3e/cb2e0b6001fb0f6fe895d005a2b99f22e263.pdf (accessed on 16 July 2020).

84. Onyemekara, N.N.; Nwanebu, F.C.; Njoku, M.N.; Chinakwe, E.C.; Nwogwugwu, N.U.; Mike-Anosike, E. Microbiological and Proximate Analysis of a Local Food Beverage-Kunu Zaki, Sold in Owerri Municipal. Available online: https://www.futojnls.org/issues/type/volume-4-issue-2-2018/science (accessed on 16 July 2020).

85. Orutugu, L.A.; Izah, S.C.; Aseibai, E.R. Microbiological quality of Kunu drink sold in some major markets of Yenagoa metropolis. Cont. J. Biomed. Sci. 2015, 9, 9-16. Available online: https://www.academia.edu/26125017/microbiological_quality_of_kunu_drink_sold_in_some_major_ markets_of_yenagoa_metropolis_nigeria_langley_ayibawanaimi_orutugu_sylvester_chibueze_izah_and_ ebinyo_rebecca_aseibai (accessed on 16 July 2020).

86. Amusa, N.A.; Odunbaku, O.A. Microbiological and nutritional quality of hawked kunun (a sorghum based non-alcoholic beverage) widely consumed in Nigeria. Pak. J. Nutr. 2009, 8, 20-25. [CrossRef]

87. Elmahmood, A.M.; Doughari, J.H. microbial quality assessment of kunun-zaki beverage sold in Girei town of Adamawa State, Nigeria. Afr. J. Food Sci. 2007, 1, 11-15. 
88. Blessed, K.Y.; Dadah, A.J.; Uba, A. Isolation of enteric bacteria from hawked "Kunun-Zaki" in Chikun Local Government Area of Kaduna State. Am. J. Lab. Med. 2017, 2, 96. [CrossRef]

89. Rosemary, C.U.; Seghosime, R.A.; Onah Gloria, T. Assessment of the Microbiological Quality of Kunu Zaki Sold at Gariki, Enugu State, Nigeria. Biol. Environ. Sci. J. Trop. 2016. [CrossRef]

90. Braide, W.; Ukagwu, N.; Lugbe, P.B.; Akien, A.A.; Adeleye, S. Chemical properties and microbiological profile of kunu zaki, a non-alcoholic beverage. Biomed. J. Sci. Tech. Res. 2018, 4, 3731-3735. [CrossRef]

91. Umaru, G.A.; Tukur, I.S.; Akensire, U.A.; Adamu, Z.; Bello, O.A.; Shawulu, A.H.B.; Audu, M.; Sunkani, J.B.; Adamu, S.G.; Adamu, N.B. Microflora of Kunun-Zaki and Sobo drinks in relation to public health in Jalingo metropolis, North-Eastern Nigeria. Int. J. Food Res. 2014, 1, 16-21. Available online: http: //www.bluepenjournals.org/ijfr/pdf/2014/September/Umaru_et_al.pdf (accessed on 16 July 2016).

92. Gaffa, T.; Gaffa, A. Microbial succession during "kunun Zaki” production with sorghum (Sorghum Bicolor) grains. World J. Microb. Biot. 2004, 20, 449-453. [CrossRef]

93. Adeniji, P.O. Nutritional, sensory and microbiological quality assessment of fortified zobo drink: A home-prepared traditional Nigerian beverage. J. Nutr. Food Sci. 2017, 07, 1-3.

94. Shruthi, V.H.; Ramachandra, C.T.; Nidoni, U.; Hiregoudar, S.; Naik, N.; Kurubar, A.R. Roselle (Hibiscus sabdariffa L.) as a source of natural colour: A Review. Plant Arch. 2016, 2, 515-522.

95. Fasoyiro, S.B.; Babalola, S.O.; Owosibo, T. Chemical Composition and Sensory Quality of Fruit-Flavoured Roselle (Hibiscus Sabdariffa) Drinks. World J. Agric. Sci. 2005, 1, 161-164.

96. Omemu, A.M.; Edema, M.O.; Atayese, A.O.; Obadina, A.O. A Survey of the microflora of Hibiscus sabdariffa (Roselle) and the eesulting "Zobo" Juice. Afr. J. Biotechnol. 2006, 5, 254-259.

97. Odu, N.N.; Adeniji, A.O. Microbiological analysis of some packaged fruit juices sold in Port Hacourt metropolis. Niger. Nat. Sci. 2013, 11, 30-40.

98. Oku, Y.I.; Alagoa, K.J.; Daworiye, P.S.; Izon-ebi, B.M. Microbial content of Zobo drink from five different producers within Yenagoa City Bayelsa State, Nigeria. Am. Sci. Res. J. Eng. Technol. Sci. 2018, 4, 74-89. Available online: https:/ijasre.net/index.php/ijasre/article/view/868/1480 (accessed on 16 July 2020).

99. Ezeigbo, O.; Ekaiko, M.; Agomo, N.; Ojukwu, K.; Nnadozie, A. Antimicrobial effect of lime juice treatment on the shelf-life of zobo drink. Br. Microbiol. Res. J. 2015, 6, 147-153. [CrossRef]

100. Onuoha, S.C.; Fatokun, K. Effect of Citrus Aurantifolia Juice on the Shelf-Life of Zobo drink produced locally in Afikpo Ebonyi State, Nigeria. Am. J. BioSci. 2014, 2, 45. Available online: http://www.sciencepublishinggroup. com/journal/paperinfo?journalid=219\&doi=10.11648/j.ajbio.20140202.14 (accessed on 15 July 2020).

101. Ezearigo, O.; Adeniji, P.; Ayoade, F. Screening of natural spices for improving the microbiological, nutritional and organoleptic qualities of the Zobo drink. J. Appl. Biosci. 2014, 76. [CrossRef]

102. Umar, M.; Mohammed, I.B.; Abdulkarim, I.M.; Yusuf, G.; Yaya, A.A.; Leo, G. Comparative studies on the prevalence of Salmonella species in two home-made fermented beverages (Zobo and Kunun-Zaki) sold at Samaru, Zaria, Kaduna, Nigeria. Int. J. Sci. Res. Publ. 2016, 6, 428-435. Available online: http://www.ijsrp.org/research-paper-0316.php?rp=P515200 (accessed on 16 July 2020).

103. Ibitoye, F.; Oyetayo, A.; Aribisala, O.; Giwa, O. Investigation of bacteria associated with the spoilage of zobo drink fortified with scent leaf and ginger. Cell. Autom. Res. Ind. 2017, 9, 1-7. Available online: https://www.journalacri.com/index.php/ACRI/article/view/18448/34113 (accessed on 15 July 2020). [CrossRef]

104. Bukar, A.; Uba, A.; Oyeyi, T.I. Occurrence of Some Enteropathogenic Bacteria in Some Minimally and Fully Processed Ready-to-Eat Foods in Kano Metropolis, Nigeria. Afr. J. Food Sci. 2010, 4, 32-36.

105. Ayandele, A.A. Microbiological analyses of hawked kunun and zobo drinks within LAUTECH campus, Ogbomoso, Oyo State, Nigeria. IOSR J. Environ. Sci. 2015, 9, 52-56.

106. Nwaiwu, O.; Itumoh, M. Molecular phylogeny of yeasts from palm wine and enological potentials of the drink. Annu. Res. Rev. Biol. 2017, 20,1-12. [CrossRef]

107. Fossi, B.T.; Natalia, B.E.; Nchanji, G.T.; Ngah, B.G.; Anyangwe, I.A.; Samuel, W.S. Probiotic properties of lactic acid bacteria isolated from fermented sap of palm tree (Elaeis guineensis). J. Microbiol. Antimicrob. 2015, $7,42-52$.

108. Nwaiwu, O. Suitability of Palm Wine as a Multifunctional Beverage. Available online: https://encyclopedia. pub/315 (accessed on 25 February 2020).

109. Okafor, N. Palm-wine yeasts from parts of Nigeria. J. Sci. Food Agric. 1972, 23, 1399-1407. [CrossRef]

110. Faparusi, S.I.; Bassir, O. Microflora of fermenting palm-wine. J. Food Sci. Technol. 1971, 8, $206-212$. 
111. Nwachukwu, I.; Ekaiko, M.U.; Stephen, C. Microbiological quality of palm wine (Elaeis Guineensis and Raphia Hookeri) sold within Aba metropolis, Abia state, south eastern Nigeria. Genet. Eng. Biotechnol. J. 2016, 3, 38-44. Available online: https://www.idpublications.org/wp-content/uploads/2016/03/Full-Papermicrobiological-quality-of-palm-wine-elaeis-guineensis-and-raphia-hookeri-sold-within-aba-metropolis. pdf (accessed on 14 July 2020).

112. Onwumah, M.; Okoronkwo, P.; Effiong, E. Molecular characterization of yeast isolated from palm wine in Alakahia, Rivers State, Nigeria. World Sci. News 2019, 130, 297-304.

113. Eze, C.O.; Berebon, D.P.; Gugu, T.H.; Nworu, C.S.; Esimone, C.O. Effects of Lactobacillus Spp. isolated from the sap of palm tree Elaeis guineensis (palm wine) on cellular and innate immunity. Afr. J. Microbiol. Res. 2019, 13, 33-39. [CrossRef]

114. Olowonibi, O.O. Isolation and characterization of palm wine strains of Saccharomyces cerevisiae potentially useful as bakery yeasts. Eur. J. Exp. Biol. 2017, 7. [CrossRef]

115. Nwakanma, C.; Unachukwu, N.M.; Onah, P.; Engwa, A.G. Isolation and sensory evaluation of Saccharomyces cerevisiae from palm wine (Elaeis guinneensis) gotten from different sites in Enugu. Eur. J. Pharm. Sci. 2015, 2, 19-26. Available online: https://www.ejbps.com/ejbps/abstract_id/677 (accessed on 15 July 2020).

116. Femi-Ola, T.O.; Falegan, C.R.; Adebule, O.M. Isolation and distribution of Bacillus strains in some Nigerian food and drinks. Int. J. Agric. Innov. Res. 2014, 2, 717-719. Available online: https://ijair.org/index.php/ issues? view=publication\&task=show \&id=181 (accessed on 14 July 2020).

117. Chilaka, C.A.; Obidiegwu, J.E.; Akpor, O.B. evaluation of the efficiency of yeast isolates from palm wine in diverse fruit wine production. Afr. J. Food Sci. 2010, 4, 764-774.

118. Gberikon, G.M.; Ichor, T.; Omeche, E.T. Effect of bitter leaf extract (Vernonia amygdalina) on culturable microorganisms isolated from palm wine in Makurdi metropolis. Res. J. Microbiol. 2016, 11, 112-118. [CrossRef]

119. Nkemnaso, C.; Ifeanyi, N. Microbiological and nutritional status of palm wine from Umudike and its Environs. Int. J. Bioinform. Biomed. Eng. 2019, 4, 62-69. Available online: http://www.aiscience.org/journal/ paperInfo/ijbbe?paperId=4265 (accessed on 14 July 2020).

120. Danmadami, R.N.; Yabaya, A.; Yahaya, O.; Abraham, O.J.; Orukotan, A.A. The efficiency of Saccharomyces cerevisiae strain isolated from palm wine in the production of Burukutu. Int. J. Res. 2018. [CrossRef]

121. Ebbah, L.; Laryea, D.; Barimah, J.; Djameh, C. Effect of Steeping temperature on the quality of malt and Pito (an indigenous Ghanaian drink). J. Inst. Brew. 2015, 121, 518-523.

122. Ekundayo, J.A. The production of Pito, a Nigerian fermented beverage. Int. J. Food Sci. Technol. 1969, 4, 217-225. [CrossRef]

123. Kolawole, O.M.; Kayode, R.M.O.; Akinduyo, B. Proximate and microbial analyses of Burukutu and Pito produced in Ilorin, Nigeria. Afr. J. Biotechnol. 2007, 6, 587-590.

124. Gazuwa, S.; Jaryum, K.; Mafulul, S. Organic contaminants and microbial load of native beers locally prepared within Jos metropolis. J. Appl. Life Sci. Int. 2016, 8, 1-7. [CrossRef]

125. Fadahunsi, I. Biomass yield and antimicrobial substances production in limiting nutrient cultures of lactobacillus Species. Trakia J. Sci. 2015, 13, 51-58. [CrossRef]

126. Eneji, I.S.; Asan, A.A.; Itodo, A.U. Physicochemical and microbial analysis of locally fermented drinks (burukutu and pito) from cereals in north central Nigeria. FUW Trends Sci. Technol. J. 2020, 5, 433-438. Available online: https://pdfs.semanticscholar.org/409f/d485dbb18fcf946f6b5acc1a4868d3d25c4e.pdf (accessed on 12 July 2020).

127. Adesina, I.A.; Ojokoh, A.O.; Arotupin, D.J. Inhibitory properties of lactic acid bacteria again moulds associated with spoilage of bakery products. Adv. Microbiol. 2017, 4, 1-8. [CrossRef]

128. Sanni, A.I.; Lonner, C. Identification of yeasts isolated from Nigerian traditional alcoholic beverages. Food Microbiol. 1993, 10, 517-523. [CrossRef]

129. Jimoh, S.O.; Ado, S.A.; Ameh, J.B.; Whong, C.M.Z. Characteristics and diversity of yeast in locally fermented beverages sold in Nigeria. World J. Eng. Pure Appl. Sci. 2012, 2, 41. Available online: https://www.academia.edu/9236428/Characteristics_and_Diversity_of_Yeast_in_Locally_Fermented_ Beverages_Sold_in_Nigeria (accessed on 12 July 2020).

130. Adelekan, A.O.; Arisa, N.U.; Alamu, A.; Adebayo, Y.O.; Omolara, O. The effect of some fruits addition on the nutritional, microbiological and sensory qualities of sorghum (Sorghum bicolour) based Pito. Int. J. Food Sci. 2013, 2, 61-69. 
131. Orji, M.U.; Mbata, T.I.; Aniche, G.N.; Ahonkhai, I. The Use of starter cultures to produce 'Pito', a Nigerian fermented alcoholic beverage. World J. Microbiol. Biot. 2003, 19, 733-736. [CrossRef]

132. Faparusi, S.I.; Olofinboba, J.A.; Ekundayo, J.A. The microbiology of Burukutu beer. Z. Allg. Mikrobiol. 1973, 13, 563-568. [CrossRef]

133. Chilaka, C.A.; de Boevre, M.; Atanda, O.O.; de Saeger, S. Quantification of Fusarium mycotoxins in Nigerian traditional beers and spices using a multi-mycotoxin LC-MS/MS method. Food Control 2018, 87, 203-210. [CrossRef]

134. Owuama, C.I. Production of Burukutu with Saccharomyces cerevisiae variants. Appl. Microbiol. Biotechnol. 1991, 35, 21-22. [CrossRef]

135. Anaukwu, C.G.; Nwangwu, F.C.; Okafor, O.I.; Ezemba, C.C.; Orji, C.C.; Agu, K.C.; Archibong, E.J. Microbiological analysis of Burukutu beverage produced in Southern part of Nigeria. Eur. J. Exp. Biol. 2015, 5, 18-22.

136. Falegan, C.R.; Akoja, S.O. Microbiological and Physicochemical Studies of Two Nigerian Fermented Alcoholic Drinks (Palmwine and Burukutu) in Ekiti State, Nigeria. Available online: http://www.eajournals.org/wp-content/uploads/Microbiological-and-Physicochemical-Studies-ofTwo-Nigerian-Fermented-Alcoholic-Drinks-Palmwine-and-Burukutu-In-Ekiti-State-Nigeria.pdf (accessed on 13 July 2020).

137. Lynn, M.; Alibe, W.; Brisca, J.; De, N. Isolation of some pathogens in Burukutu, a local drink, sold in Sengere Village, Girie Local Government, Adamawa State. Greener J. Microbiol. Antimicrob. 2014, 2, 1-6. [CrossRef]

138. Alo, M.N.; Eze, U.A.; Eda, N.E. Microbiological Qualities of Burukutu Produced from a Mixture of Sorghum and Millet. Available online: https://www.academia.edu/5908608/Microbiological_qualities_of_burukutu_ produced_from_a_mixture_of_sorghum_and_millet (accessed on 13 July 2020).

139. Stanley, M.C.; Ifeanyi, E.; Chinedum, O.K.; Christopher, O.N. Effect of ginger and garlic on the microbial load and shelf-life of Burukutu. Int. J. Microbiol. Res. 2014, 5, 117-123.

140. Yabaya, A. Microorganisms associated with starter cultures of traditional Burukutu liquor in Madakiya, Kaduna state, Nigeria. Sci. World J. 2008, 3, 9-11. [CrossRef]

141. Eze, V.; Eleke, O. Microbiological and Nutritional Qualities of Burukutu Sold in Mammy Market Abakpa, Enugu State, Nigeria. Available online: https://pdfs.semanticscholar.org/8fed/ bc93603285299d1014e3b7a0751b58008805.pdf?_ga=2.120659776.955855744.1594937732-672785399. 1575931509 (accessed on 14 July 2020).

142. Olaniyi, O.O.; Akinyele, J.B. Isolation of toxigenic Aspergillus flavus and evaluation of aflatoxins in "Burukutu", sorghum fermented beverage sold in Akure, Nigeria. J. Food Safe. Hyg. 2019, 5, 30-38. [CrossRef]

143. Buchanan, R.L.; Oni, R. Use of Microbiological indicators for assessing hygiene controls for the manufacture of powdered infant formula. J. Food Prot. 2012, 75, 989-997. [CrossRef]

144. Camargo, A.C.; Cossi, M.; Silva, W.; Bersot, L.; Landgraf, M.; Baranyi, J.; Franco, B.; Luís Augusto, N. Microbiological Testing for the Proper Assessment of the Hygiene Status of Beef Carcasses. Microorganisms 2019, 7, 86. [CrossRef]

145. Usman, R.Z.; Mustapha, B.M.; Mohammed, F.I. Isolation and Identification of Methicillin Resistant Staphylococcus aureus (MRSA) from Traditionally Fermented Milk "Nono" and Yoghurt in Zaria Metropolis, Nigeria. Available online: http://ijclris.com/papers/2016/feb2016/ijclris1.pdf (accessed on 14 July 2020).

146. Martin, N.H.; Trmcic, A.; Hsieh, T.H.; Boor, K.J.; Wiedmann, M. The evolving role of coliforms as indicators of unhygienic processing conditions in dairy foods. Front. Microbiol. 2016, 7, 1549. [CrossRef]

147. Ismaiel, A.A.; Papenbrock, J. Mycotoxins: Producing fungi and mechanisms of phytotoxicity. Agriculture 2015, 5, 493-537. [CrossRef]

148. Ezeronye, O.U.; Legras, J.L. Genetic analysis of Saccharomyces cerevisiae strains isolated from palm wine in eastern Nigeria. Comparison with other African strains. J. Appl. Microbiol. 2009, 106, 1569-1578.

149. Nwaiwu, O.; Ibekwe, V.I.; Amadi, E.S.; Udebuani, A.C.; Nwanebu, F.C.; Oguoma, O.I.; Nnokwe, J.C. Evaluation of fermentation products of palm wine yeasts and role of Sacoglottis gabonensis supplement on products abundance. Beverages 2016, 2, 9. [CrossRef]

150. Okolie, P.I.; Opara, C.N.; Emerenini, E.C.; Uzochukwu, S.V.A. Evaluation of bacterial diversity in palm wine by 16S RDNA analysis of community DNA. Niger. Food J. 2013, 31, 83-90. [CrossRef]

151. Banwo, K.; Sanni, A.; Tan, H.; Tian, Y. Phenotypic and genotypic characterization of lactic acid bacteria isolated from some Nigerian traditional fermented foods. Food Biotechnol. 2012, 26, 124-142. [CrossRef] 
152. Ezekiel, C.N.; Ayeni, K.I.; Ezeokoli, O.T.; Sulyok, M.; van Wyk, D.A.B.; Oyedele, O.A.; Akinyemi, O.M.; Chibuzor-Onyema, I.E.; Adeleke, R.A.; Nwangburuka, C.C.; et al. High-throughput sequence analyses of bacterial communities and multi-mycotoxin profiling during processing of different formulations of Kunu, a traditional fermented beverage. Front. Microbiol. 2019, 10, 3282. [CrossRef] [PubMed]

153. Diaz, M.; Kellingray, L.; Akinyemi, N.; Adefiranye, O.O.; Olaonipekun, A.B.; Bayili, G.R.; Ibezim, J.; du Plessis, A.S.; Houngbédji, M.; Kamya, D.; et al. Comparison of the microbial composition of african fermented foods using amplicon sequencing. Sci. Rep. 2019, 9, 1-8. [CrossRef] [PubMed]

154. Cote, C.K.; Heffron, J.D.; Bozue, J.A.; Welkos, S.L. Bacillus anthracis and other bacillus species. In Molecular Medical Microbiology, 2nd ed.; Tang, Y.W., Sussman, M., Liu, D., Poxton, I., Schwartzman, J., Eds.; Academic Press: Amsterdam, The Netherlands, 2015; Volume 3, pp. 1789-1844.

155. Ehling-Schulz, M.; Lereclus, D.; Koehler, T.M. The Bacillus cereus group: Bacillus species with pathogenic potential. Microbiol. Spectr. 2019, 7, 875-902. [CrossRef] [PubMed]

156. Cao, J.; Zhiming, Y.; Wenyin, L.; Jianxin, Z.; Hao, Z.; Qixiao, Z.; Wei, C. Probiotic characteristics of Bacillus coagulans and associated implications for human health and diseases. J. Funct. Foods 2020, 64, 103643. [CrossRef]

157. Huang, Y.; Flint, S.H.; Palmer, J.S. Bacillus cereus spores and toxins -The potential role of biofilms. Food Microbiol. 2020, 90, 103493. [CrossRef]

158. Rouzeau-Szynalski, K.; Stollewerk, K.; Messelhäusser, U.; Ehling-Schulz, M. Why be serious about emetic Bacillus cereus: Cereulide production and industrial challenges. Food Microbiol. 2020, 85, 103279. [CrossRef]

159. Chai, S.J.; Gu, W.; O'Connor, K.A.; Richardson, L.C.; Tauxe, R.V. Incubation periods of enteric illnesses in foodborne outbreaks, United States, 1998-2013. Epidemiol. Infect. 2019, 147. [CrossRef]

160. Xing, Y.; Willie, W.F. Bacillus spore awakening: Recent discoveries and technological developments. Curr. Opin. Biotechnol. 2020, 64, 110-115. [CrossRef]

161. Lentz, S.A.M.; Rivas, P.M.; Cardoso, M.R.I.; Morales, D.L.; Centenaro, F.C.; Martins, A.F. Bacillus cereus as the main casual agent of foodborne outbreaks in southern Brazil: Data from 11 Years. Cad. Saude Publica 2018, 34, e00057417. [CrossRef] [PubMed]

162. Martinelli, D.; Fortunato, F.; Tafuri, S.; Cozza, V.; Chironna, M.; Germinario, C.; Pedalino, B.; Prato, R. Lessons learnt from a birthday party: A Bacillus cereus outbreak, Bari, Italy, January 2012. Ann. Ist. Super. Sanita 2013, 49, 391-394. [PubMed]

163. Chen, D.; Li, Y.; Lv, J.; Liu, X.; Gao, P.; Zhen, G.; Zhang, W.; Wu, D.; Jing, H.; Li, Y.; et al. A foodborne outbreak of gastroenteritis caused by norovirus and Bacillus cereus at a University in the Shunyi district of Beijing, China 2018: A retrospective cohort study. BMC Infect. Dis. 2019, 19, 910. [CrossRef] [PubMed]

164. Delbrassinne, L.; Botteldoorn, N.; Andjelkovic, M.; Dierick, K.; Denayer, S. An emetic Bacillus cereus outbreak in a kindergarten: Detection and quantification of critical levels of cereulide toxin. Foodborne Pathog. Dis. 2015, 12, 84-87. [CrossRef]

165. Thirkell, C.E.; Sloan-Gardner, T.S.; Kacmarek, M.C.; Polkinghorne, B. An Outbreak of Bacillus Cereus toxin-mediated emetic and diarrhoeal syndromes at a restaurant in Canberra, Australia 2018. Commun. Dis. Intell. 2019, 43. [CrossRef]

166. Pang, B.; Zhao, C.; Li, L.; Song, X.; Xu, K.; Wang, J.; Liu, Y.; Fu, K.; Bao, H.; Song, D.; et al. Development of a low-cost paper-based ELISA method for rapid Escherichia coli O157:H7 detection. Anal. Biochem. 2018, 542, 58-62. [CrossRef]

167. Chong, Y.; Shinji Shimoda, S.; Shimono, N. Current epidemiology, genetic evolution and clinical impact of extended-spectrum $\beta$-lactamase-producing Escherichia coli and Klebsiella pneumoniae. Infect. Genet. Evol. 2018, 61, 185-188. [CrossRef]

168. Rangel, J.M.; Sparling, P.H.; Crowe, C.; Griffin, P.M.; Swerdlow, D.L. Epidemiology of Escherichia coli O157:H7 Outbreaks, United States, 1982-2002. Emerg. Infect. Dis. 2005, 11, 603-609. [CrossRef]

169. Mirhoseini, A.; Amani, J.; Nazarian, S. Review on pathogenicity mechanism of enterotoxigenic Escherichia coli and vaccines against it. Microb. Pathog. 2018, 117, 162-169. [CrossRef]

170. Abat, C.; Rolain, J.M.; Colson, P. Investigations by the Institut Hospitalo-Universitaire Méditerranée Infection of Food and Food-Borne Infections in the Mediterranean Basin and in Sub-Saharan Africa. New Microbes New Infect. 2018, 26, S37-S42. [CrossRef] 
171. Aijuka, M.; Buys, E.M. Persistence of foodborne diarrheagenic Escherichia coli in the agricultural and food production environment: Implications for food safety and public health. Food Microbiol. 2019, 82, 363-370. [CrossRef] [PubMed]

172. Doulgeraki, A.I.; Di Ciccio, P.; Ianieri, A.; Nychas, G.E. Methicillin-resistant food-related Staphylococcus aureus: A review of current knowledge and biofilm formation for future studies and applications. Res. Microbiol. 2017, 168, 1-15. [CrossRef] [PubMed]

173. Oniciuc, E.A.; Nicolau, I.A.; Hernández, M.; Rodríguez-Lázaro, D. Presence of methicillin-resistant Staphylococcus aureus in the food chain. Trends Food Sci. Technol. 2017, 61, 49-59. [CrossRef]

174. Rubab, M.; Shahbaz, H.M.; Olaimat, A.N.; Oh, D.H. Biosensors for rapid and sensitive detection of Staphylococcus aureus in food. Biosens. Bioelectron. 2018, 105, 49-57. [CrossRef]

175. Shankar, N.; Soe, P.; Tam, C.C. Prevalence and risk of acquisition of methicillin-resistant Staphylococcus aureus among households: A Systematic review. Int. J. Infect. Dis. 2020, 92, 105-113. [CrossRef]

176. Roselló-Soto, E.; Garcia, C.; Fessard, A.; Barba, F.J.; Munekata, P.E.S.; Lorenzo, J.M.; Remize, F. Nutritional and microbiological quality of tiger nut tubers (Cyperus esculentus), derived plant-based and lactic fermented beverages. Fermentation 2019, 5, 3. [CrossRef]

177. Salvetti, E.; Orrù, L.; Capozzi, V.; Lamontanara, A.; Keller, D.; Cash, H.; Cattivelli, L.; Torriani, S.; Spano, G. Integrate genome-based assessment of safety for probiotic strains: Bacillus coagulans GBI-30, 6086 as a case study. Appl. Microbiol. Biotechnol. 2016, 100, 4595-4605. [CrossRef]

178. Mahboubi, A.; Ferreira, J.A.; Taherzadeh, M.J.; Lennartsson, P.R. Production of fungal biomass for feed, fatty acids, and glycerol by Aspergillus oryzae from fat-rich dairy substrates. Fermentation 2017, 3, 48. [CrossRef]

179. Tufariello, M.; Capozzi, V.; Spano, G.; Cantele, G.; Venerito, P.; Mita, G.; Grieco, F. Effect of co-inoculation of Candida zemplinina, Saccharomyces cerevisiae and Lactobacillus plantarum for the industrial production of Negroamaro wine in Apulia (Southern Italy). Microorganisms 2020, 8, 726. [CrossRef]

180. Silla Santos, M.H. Biogenic amines: Their importance in foods. Int. J. Food Microbiol. 1996, 29, $213-231$. [CrossRef]

181. Russo, P.; Fragasso, M.; Berbegal, C.; Grieco, F.; Spano, G.; Capozzi, V. Microorganisms able to produce biogenic amines and factors affecting their activity. In Biogenic Amines in Food: Analysis, Occurrence and Toxicity, 1st ed.; Saad, B., Tofalo, R., Eds.; Royal Society of Chemistry Publishing: Cambridge, UK, 2020; pp. 18-40.

(C) 2020 by the authors. Licensee MDPI, Basel, Switzerland. This article is an open access article distributed under the terms and conditions of the Creative Commons Attribution (CC BY) license (http://creativecommons.org/licenses/by/4.0/). 